\title{
Analysis of the Value of Character Education in the Folklore of Nan Sondang Ngilong-Ilong in Mandailing Natal
}

\author{
Hasibuan Nikmah Sari ${ }^{1}$, Idawati ${ }^{2}$, Khairunnisah ${ }^{3}$, Rukiah ${ }^{4}$ \\ ${ }^{1,2,3,4}$ Universitas Muhammadiyah Tapanuli Selatan, Indonesia \\ nikmah.sari@um-tapsel.ac.id
}

\begin{abstract}
This study aims to describe the value of character education contained in the folklore of Nan Sondang Ilong-Ilong. The data in this study are folk tales obtained from recording and written documentation. The method used in this research is descriptive analysis method. The data collection technique used is the note-taking technique. The results showed that the values of character education contained in the folklore of Nan Sondang Ilong-Ilong are very good for shaping human character from an early age. The value of character education contained in the folklore of Nan Sondang Ilong-Ilong can contribute to today's world because the value of character education contained in the folk lore of Nan Sondang Ilong-Ilong is an educational value that is very close to everyday life so it is very suitable for instilled in oneself. In the folklore of Nan Sondang Ilong-Ilong, there are four values of character education, namely: the value of responsibility, hard work, mutual care, and compassion.
\end{abstract}

Keywords value of character education; folklore; Mandailing Natal

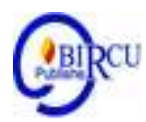

\section{Introduction}

Basically, folklore is a type of oral literature. Where, oral literature is part of Indonesian culture. Oral literature is defined as literature that lives orally and is spread in an unwritten form, told orally from generation to generation from generation to generation. Folk stories are passed on by word of mouth and from generation to generation. Folklore is a type of literature that is often told by a teacher to students, parents to their children, society and speakers to listeners (Andayani, 2018; Kahar, et.al., 2019; Sapirin, et.al., 2019; Sundari, et.al., 2017).

Folklore is not only a tool for telling stories, but also as a tool for educating the public. Folklore is rich in moral values and local wisdom, which can be used as a means of communication to teach educational values about life to the community (Gusnetti, et al, 2015). Wiguna (2018), folklore as a literary work that is full of messages, contains exemplary, philosophical values, educational values, moral values, ethical values that are beneficial to national development. Drani, et all (2021), folklore is part of the cultural and historical wealth possessed by the Indonesian nation. In general, folk tales tell about an event in a place or the origin of a place. The characters that appear in folklore are generally manifested in the form of animals, humans and gods. Drani, et. al. (2021) the function of folklore apart from being entertainment, can also be used as role models, especially folk tales that contain messages of moral education.

Based on the above opinion, it can be concluded that folklore contains life values that are very important for children. However, this is very unfortunate because in reality this type of folklore oral literature is not significant with the government's efforts to preserve and 
document regional oral literature, and even in school learning, teachers do not pay more attention to oral literature that is in their own region. In fact, the existing folklore contains the values of life, including the value of character education, which will be used as material in building and developing children's character.

Abdillah, et, al (2019) states that internalization of character education for students can be done in various ways and media. Starting from direct learning, field learning, writing media at school through literary works. The character education is launched to present philosophical values and to present the whole character of the nation as a whole and overall, both self-character and national character (Khomsilawati, 2017)

One of the oral literatures that developed in Mandailing Natal Regency and its existence is almost extinct, namely the folk tale of Nan Sondang Ngilong-Ilong which, if one looks at it, contains noble values that can be applied in life. This is due to the development of the times that increasingly forget the existing traditions. At this time, only a small part of the younger generation, especially those in Mandailing Natal District, still recognize the existence of folk tales in their area. This is due to the absence of successors and the willingness of individuals to recognize stories that contain the noble values of life. This is what motivates the author to conduct research on the value of character education contained in the folklore of Nan Sondang Ngilong-Ilong.

The problem raised in this study is to see how the values of character education are contained in the folklore of Nan Sondang Ngilong-Ilong which aims to describe the values of character education contained in the folklore of Nan Sondang Ngilong-Ilong, and to see whether there is a value in character education that is contained in the folklore of Nan Sondang Ilong-ilong.

\section{Review of Literatures}

\subsection{Value of Character Education}

Education is not a foreign term in today's society. Education is an effort made to advance character, mind and body patterns of children in harmony with nature and society. Education has an important role for every individual. Where, good education is education that can prepare students to be able to access their role in the future. In other words, through education a person will grow with good character and be able to adapt.

The term character comes from the Greek charassei which means to carve into a pattern and "to mark" (to mark). This term focuses more on action or behavior. In the Big Indonesian Dictionary (KBBI) character means character, character, mental, moral, or character that distinguishes a person from others. According to Hidayah (2015) character describes a person's behavior patterns that are formed from a belief system and habits. This can be seen from one's daily behavior and thinking patterns. The values inherent in a person also describe the character he already has.

The character is a process to foster the values of life in a person's personality, so that they can integrate with their behavior in life (Gaffar, 2010). The character education as a dynamic condition of an individual's anthropological structure which attempts to live an increasingly integral life overcoming natural determinations in it for the process of continuous self-improvement (Koesoema, 2007). Sibarani (2012: 138) states that character is the whole values, thoughts, words, and behavior or actions that have shaped of a person. Raharjo (2010) explains that character education is a process of education that thoroughly connects the moral dimension with the social environment in the lives of students as the basis for the formation of an independent and quality generation and can also be accounted for 
accordance with the principle of truth. Purba, et all (2020) definies character education can be interpreted as value, character, and moral education. It aims to give and maintain good decisions and realize goodness in everyday life wholeheartedly. Ramli (2003) states that character education has the same essence and meaning as moral education.

Character education is a conscious effort undertaken in shaping students to become positive personalities, with moral values referring to graduate competency standards (SKL) so that they can be implemented in everyday life In detail (Otaya, 2014). Agreeing with that, Saptono (2011) argues that character education is an educational effort in developing a good character based on virtues objectively both for themselves and the community. In detail In detail, Lickona (2013) states that character education includes three important things, namely first, moral knowledge in the form of moral awareness, moral value knowledge, moran thought, decision making, and personal knowledge; second, moral feelings about conscience, self-esteem, empathy, loving good things, self-control and humility; and finally, moral actions in the form of competencies, desires, and habits.

Suyatno (Asriyati, et all, 2020), Character education in Indonesia has eighteen aspects taught to students, the ministry of National Education formulating character vaalues, as follows: (1) religious, (2) honest, (3) tolerance, (4) discipline, (5) hard work, (6) creative, (7) independent, (8) democratic, (9) curiosity, (10) national spirit, (11) patriotism, (12) respect achievement, (13) friendly / communicative, (14) peace-loving, (15) fond of reading, (16) caring for the environment, (17) caring socially, (18) responsibility.

\subsection{Folklore}

The term folklore refers to stories that are part of the people, namely literary products that are included in the scope of focus. Folklore is a form of oral literary work that was born and developed from a traditional society that is disseminated in a relatively fixed form and among certain collectives for quite a long time using clichés (Danandjaja, 2007). In general, folklore tells about an event in a place or the origin of a place. The characters that appear in folklore are generally manifested in the form of animals, humans or gods. Folklore can be interpreted as a cultural expression of a society through spoken language which is directly related to various aspects of culture and the composition of the social values of the community.

According to Danandjaja (2007), folklore is a form (genre) of fochlor. The phochlor itself is a part of the culture of a collective that is spread and passed down from generation to generation among any kind of collective, traditionally in different versions, either in verbal form or in examples accompanied by gestures or memonic devices.

Folklore is one of the old literary works that was passed down orally which contains events that may occur or are just imagination and are a description of the people who own them. Folklore is found in all tribes in Indonesia. Its contents reveal not only surface matters, but also the joints of life in a deeper way (Rismawati, 2017: 19). In fact, the folklore contains a lot of structured messages and messages conveyed implicitly (Marsellaa and Putri, 2020).

Based on this opinion, it can be seen that folklore is a scope of fochlor that developed in the past and was passed down orally. Because it was passed down orally, the story often received variations or additions. This really depends on the skill of the storyteller / storyteller. Thus, the same story may be told in different versions. 


\section{Research Methods}

The method used in this research is a qualitative descriptive method with a content analysis research model. The method used in this study aims to obtain accurate data so as to facilitate the analysis process. Junaina (2017) states that the content analysis model is a research model used to understand and express messages in a literary work. In this case, to find the value of character education contained in the folklore of Nan Sondang Ilong-Ilong.

This research was conducted in the Mandailing Natal area. The data in this study are folk tales that contain the values of character education contained in the folklore of Nan Sondang Ilong-Ilong which is the result of a researcher recording and then made in writing.

Sources of data in this study are people who can provide complete and accurate information related to research data in the form of folklore in Mandailing Natal. The informants selected in this study were indigenous people of Mandailing Natal who not only understood folklore, but also understood matters related to local culture and fulfilled the requirements as informants. The data collection technique in this study is a note-taking technique, which is data collection by recording informants who are native speakers of the oral literature. The instrument in a study is a tool used to collect data.

The instrument in this study was the researcher himself or a human instrument. The tools used in collecting data in the form of folklore are interview guides, stationery equipment, digital recorders that will help to obtain data in the form of recordings, photos and other important things. The data analysis techniques used in this research are; a) Record data transcription; b) Transliteration / translation; c) Classification of data; d) Structural analysis and search for meaning; e) Testing data.

\section{Discussion}

Folklore that is hereditary is not only used as a media to tell stories, but folklore is also considered as a means of conveying the values of character education for the community, especially the people who own it. By listening to and understanding the stories, someone will be able to take and make it a teaching or education that can be applied in everyday life. Everyone needs education, not only formal education such as school, but also non-formal ones such as those derived from experiences or stories told by ancient people or often referred to as folk tales.

One of the folk tales that is considered to provide lessons and education about life is a folk tale entitled Nan Sondang Ilong-Ilong which originates from Mandailing Natal. Based on the analysis that has been carried out by researchers, there are several values of character education in the folklore, namely as follows:

\subsection{The Value of Responsibility}

The nature of responsibility we must instill in ourselves. Responsibility is not just a matter of taking responsibility for what we do ourselves. The responsibility also involves parents and their children, the government and the people, the king and the people, and vice versa. The value of this responsibility can be seen from the traits shown by Nan Sondang's father who is responsible for Nan Sondang in raising him to adulthood and finding a mate for Nan Sondang even though Nan Sondang's mother is no longer there.

In the folklore of Nan Sondang Ilong-Ilong, there is a value of responsibility by the king to the people and the village. Where, in order to cover up the disgrace of the people 
and their village, the king allowed Nan Sondang to hold a Manortor party to find a mate. Because in the story there is a woman who has not been married at 16 years of age will be a disgrace and a curse for the village itself. This can be seen from the following story excerpt:

"ma marumur ma boru ki tai napedo marbagas ia. Mabiar au manjadi aib di kampung on raja”. Ning ayah Nan Sondang tu raja $i$.

Mambege ayah si Nan Sondan, raja pe mangoloon pangidoan ni ayah Nan Sondang

"My child is old and he is not married yet, this will be a disgrace for this village," said Aayah Nan Sondang.

Hearing that reason, the king finally agreed to hold a big party in the village

\subsection{The Value of Compassion Education}

The value of compassion education does not only encourage parental love for their children. But also the child's love for their parents. Affection for parents is an obligation that must be carried out. The love of parents for their children cannot be described or even measured because in fact the love of parents has no limits. As children we must also love and cherish our parents sincerely, where we can make them happy and happy by fulfilling their wishes. As in the folklore of Nan Sondang. Nan Sondang does not want to see her father continue to be sad and begs other people to persuade her to marry. In the end he thought of a way to return his father's smile. He said that he wanted to get married even though to be honest he really didn't want to get married and was just looking for an excuse. This can be seen from the following story excerpt:

jobos-jobos ro si Nan Sondang dompak mradu kecet ayah dot bouk nia gara-gara inda ra bouk nia mambujuk ia so ra marbagas.

Diarma ayah, ra ma au na lakka matobang i. tai au do mamili jodoh ku, oni ayah adaon ma orja manortor so upili jodohku" ning si Nan Sondang

Di paligi ayah nia ma ia. Tarsonggot ayah nia mambegena. Peto don inang? Ning ayah nia

Bopena tola mambaen orja manortor baen manjalaki jodoh di kampung I, baen sonang roa ni ayah nia mambege kecek niaa I, di oloon ayah nia hagiotan nia bopena kan mamohon-mohon ayah nia tu raja kampung $i$.

Suddenly Nan Sondang came in the middle of a fight between her father and aunt. Nan Sondang's father ordered his aunt to persuade him to marry, but his aunt was unable to persuade Nan Sondang.

"Okay, I am willing to marry on one condition. I choose my own soul mate. That's why we have a Manortor party. At the party I will match myself up" said Nan Sondang.

Although actually not allowed to hold parties in the context of finding a mate. Because Nan Sondang's father's heart was very happy to hear that his son was getting married, Nan Sondang's father was willing to beg the king.

From the quote above, it is clear that Nan Sondang and her father love each other. Nan Sondang doesn't want his father to be sad and Nan Sondang's father always grants his son's wish. 


\subsection{The Value of Hard Work}

The folklore of Nan Sondang Ilong-Ilong contains the character value of hard work. Hard work is defined as an effort or work that is carried out continuously tirelessly. Hard work can also be interpreted as an action or deed that is taken seriously and seriously until a goal is achieved. Islam teaches its ummah to always work hard to make ends meet. Apart from working hard, we also have to pray to HIM and we are encouraged to be patient in facing the test so that we can achieve what we want.

As humans we are ordered to work. The forms of hard work are of course very diverse. Working hard is not only about someone having to continue working from morning to night so that they forget about their other rights and obligations. However, the meaning of working hard here is more about seriously doing something so as to achieve the desired results, the character of hard work implied by Nan Sondang's father is to keep trying as a parent to support, teach and guide his child so that he grows into a very smart girl even though he only raised Nan Sondang alone without a wife to accompany him. And the character of hard work that is written in this story is the effort of a father who is not tired and keeps trying to find ways to persuade his daughter to accept the proposal and want to get married. This can be seen from the following quote:

Na binoto be sana sojia mandokonna so ra Nan sondang marbagas" ning ayah nan sondang tu bouk ni Nan Sondang. Sampe akhirna O nggik e, loja ma ulala mangelek si nan sondang. Elek ma jolo lakna si Nan Sondang so ra ia na langkai. Marumur ma ia da nggik. Inda uboto be sana sonjia mambujuk ia. Les inda pe dot marbagas au ayah nia sajo jawabna.

'I don't know anymore how to persuade Nan Sondang to get married. My sister please persuade Nan Sondang so that she wants to get married, she is not young anymore, she is an adult", asked Nan Sondang's father to Nan Sondang's aunt.

From the quote above, it can be seen that even though Nan Sondang's father has done various ways to persuade Nan Sondang, his father does not give up and continues to look for ways even though it involves Nan Sondang's father.

\subsection{Caring Character Value}

The value of caring character can be seen from the actions of Nan Sondang who always think of his people, even though he himself is in a precarious situation. Where can be seen clearly in the following quote:

"inda get marbagas au ayah, get marguna dope au di masyarakat on. Gumenan dope jadi ayu bargot au daripada marbaga. Mala jadi bargot au "aek mata ku bisa jadi gulo, obuk ku jadi ijuk, tanganku jadi bakkar dot bulung, badanku manjadi batang, pat ku manjadi urat" mala jadi barot au bisa igunaon rakyat on au"ning si Nan Sondang

"I don't want to get married. Instead of getting married, Mendin Sauya just turned into a palm tree. "My tears turn to sugar palm, my hair becomes palm fibers, my hands become fronds and leaves, my body becomes a trunk, my feet become roots". If I become a palm tree, I will be very beneficial for the community, "shouted Nan Sondang.

From the quote above, we can see Nan Sondang's concern for his people. She prefers to turn into a palm tree so that it can be used by everyone rather than marrying. Basically all parts of the palm tree can be used. The water produced by palm trees can be 
processed into sugar, the fibers become brooms, the leaves become roofs, the fruit can be eaten and the stems can be processed into flour. Apart from Nan Sondang's concern, there was also the king's concern for Nan Sondang's father who asked to give permission for Nan Sondang's matchmaking party. Seen in the quote below:

Ro ayah Nan Sondang manghadop tu raja. Di paboa ayah Nan Sondang ma hagiotan bahaso na get mambaen orja manortor si Nan Sondang baen manjalaki jodoh.

Pajolona inda dipalobas raja hagiotan ni Nan Sondang. Tai ayah nia les mangido tolong.

“maidotolong ma raja, so ra si Nan Sondang marbagas” ning ayah Nan Sondang.

“diarma sanolian upalobas ma, karejoonma hagiotan ni Nan Sondang I" ni rajai.

Nan Sondang's father went to the King to ask permission about Nan Sondang's request. Nan Sondang's father told the king his son's wish, that Nan Sondang asked to hold a Manortor party in the village.

At first hearing this the king was angry because there was no custom of the Manortor party in the search for a mate.

"Help me, the king, this is the only way to get Nan Sondang married" asked Nan Sondang's father

"Alright then, just this time I will allow you to hold a Manortor party as Nan Sondang wishes" replied the king.

\section{Conclusion}

Based on the results of the research, it was found that there are four values of character education in the folklore of Nan Sondang Ilong-Ilong, which include the character values of responsibility, hard work, character values of affection and values of caring characters.

1. Value the Character of Responsibility

The nature of responsibility we must instill in ourselves. Responsibility is not only a matter of parents with their children, children with their parents, responsibility towards ourselves but we must be responsible for everything we have done and what has been mandated for us.

2. Value the character of hard work

Everyone must have the value of hard work character. Because only by working hard can we achieve our goals, only by working hard can we get what we want.

3. Value the character of affection

The value of compassion education does not only encourage parental love for children. But the child's love for parents. From the folklore of Nan Sondang IlongIlong it can be concluded that both father and Nan Sondang loved each other.

4. The value of the caring character.

As social beings we cannot live alone, therefore we should not be indifferent to other people, because in fact we cannot without help from others. We must be caring and tolerant of our surroundings. Not only fellow humans, but everything around us including animals and plants. 


\section{References}

Abdullah, A. R., Waluyo, H. J., \& Wardani, N. E. 2019. The Value of Social Care Character Education Through Merindu Baginda Nabi. Budapest International Research and Critics in Linguistics and Education (BirLE) Journal, 2(4), 98-105.

Andayani, T., Puspita, Juliarti. 2018. Upaya Menebarkan Nilai-Nilai Kebaikan Melalui Pelatihan Mendongeng bagi Siswa/I Sekolah Dasarabdi Kecamatan Percut Sei Tuan, Anthropos: Jurnal Antropologi Sosial dan Budaya (Journal of Social and Cultural Anthropology), 3(2): 61-68

Danandjaja, James. 2007. Folklor Indonesia, Ilmu Gosip, Dongeng, dan lain-lain. Jakarta: Pustaka Utama Grafiti.

Drani, A., Adisaputera, A., \& Wuriyani, E. P. 2021. Effectiveness of Using Folklore TextBased Learning Media Literacy in Class X Students of MAN Tg. Pura. Budapest International Research and Critics in Linguistics and Education (BirLE) Journal, 4(1), 377-391.

Gaffar, F. 2010. Islamic-Based Character Education (Jogjakarta: Papers Religion-Based Character Education Workhsop p.4, July 22, 2010).

Gusnetti. Syofiani. \& Isnanda, Romi. 2015. Struktur dan Nilai-Nilai Pendidikan dalam Cerita Rakyat Kabupaten Tanah Datar Provinsi Sumatera Barat. Jurnal Gramatika, 1 (2): $183-192$

Koesoma. (2007). Character Education: A Strategy for Educating Children in the Age Global. Jakarta: Grasindo.

Hidayah, Nurul. 2015. Penanaman Nilai-Nilai Karakter dalam Pembelajaran Bahasa Indonesia di Sekolah Dasar. Terampil: Jurnal Pendidikan dan Pembelajaran Dasar. 2 (2): 190-204.

Kahar, S, Barus, M.I \&Wijaya, C. 2019. Peran Pesantren dalam Membentuk Karakter Santri, Anthropos: Jurnal Antropoloi Social dan Budaya (Journal of Social and Cultural Anthropology), 4 (2): 170-178

Lickona, Thomas. 2013. Educating for Character: Mendidik Untuk Membentuk Karakter. Jakarta: PT Bumi Aksara.

Marsellaa, E., Putri, D., M. (2020) Folklore as Ethnic Embodiment Bias: Value Analysis on Karo Folklore. Budapest International Research and Critics Institute-Journal (BIRCI-Journal), 2619-2628.

Rismawaty.(2017). Perkembangan Sejarah Sastra Indonesia. Banda Aceh: Bina Karya Akademika

Otaya, Lian G. 2014. 'Pendidikan Karakter Berbasis Nilai". Nadwa: Jurnal Pendidikan Islam 8(1): 75.

Purba, S. K., Angin, R. B. P., \& Yus, A. 2020. The Development of Teaching Materials of Bhineka Tunggal Ika by Integrating Character Education Using Contextual Learning. Budapest International Research and Critics in Linguistics and Education (BirLE) Journal, 3(4), 2221-2232.

Raharjo, Sabar Budi. 2010. "Pendidikan Karakter sebagai Upaya Menciptakan Akhlak Mulia”. Jurnal Pendidikan dan Kebudayaan, Vol.16,3,229-238.

Sapirin, Adlan, \& Wijaya, C. 2019, Implementasi Mata Pelajaran Akidah Akhlak dalam Pembentukan Karakter Siswa Madrasah Ibtidaiyah Negeri 3 Tapanuli Tengah. Anthropus: Jurnal Antropologi Sosial dan Budaya (Journal of Social and Cultural Anthropology), 4 (2): 211-220. 
Sibarani, Robert. 2012. Kearifan Lokal; Hakikat, Peran dan metode Tradisi Lisan. Jakarta: Asosiasi Tradisi Lisan (ATL).

Saptono. 2011. Dimensi-Dimensi Pendidikan Karakter: Wawasan, Strategi, Dan Langkah Praktis. Jakarta: Erlangga.

Sundari, F., Ernata S., Nurmi R., dan Sulian E., 2017. Penerapan Program FOS (Folktale Speaking) sebagai Pembentuk Karakter Anak Usia Dini. Jurnal Pendidikan IlmuIlmu Sosial, 9 (1): 102-111.

T. Ramli. 2003. Pendidikan Karakter. Bandung: Angkasa

Wiguna, M, Z., \& Alimin, A.A. 2018. Analisis Nilai-Nilai Moral dalam Cerita Rakyat Kalimantan Barat. Jurnal Pendidikan Bahasa IKIP PGRI, 7 (1): 143-158. 